\title{
Editorial
}

\section{Investigación Clínica resiste los embates de la situación política, económica y social en Venezuela.}

Investigación Clínica concluyó el año 2017 con éxito, a pesar de haber sido un año lleno de conflictos en Venezuela. Gracias al eficiente trabajo del equipo Editorial y de algunos colaboradores financieros, se ha logrado que, a pesar de no haber contado con el aporte presupuestario del Consejo de Desarrollo Científico y Humanístico, ni de la Facultad de Medicina, de la Universidad del Zulia, la frecuencia de los cuatro números no fue alterada, y sus contenidos aparecieron en la WEB en el mes establecido, a través de la página de la revista ( https://sites.google.com/ site/revistainvestigacionesclinicas/) y de la página de los Servicios Bibliotecarios de LUZ, Serbiluz (http://produccioncientifica.luz.edu. ve), al mismo tiempo que fueron enviados a los índices internacionales. Desafortunadamente el déficit financiero, nos ha obligado a incrementar el aporte que a manera de colaboración, se le solicita a los autores de los trabajos aceptados, con la esperanza de que sepan comprender esta decisión.

Se recibieron 69 trabajos para publicación, cifra superior a la del año anterior. Otro logro ha sido recibir una alta proporción ( $61,8 \%)$, de trabajos provenientes de otros países, principalmente latinoamericanos: México contribuyó con un $30,9 \%$ de los trabajos (algunos de ellos en colaboración con España y Colombia), seguido por Colombia, Ecuador, Perú, Honduras, Chile, Argentina, y Cuba, y por países más lejanos como España, Turquía y China. Un agradecimiento especial para los árbitros consultados quienes, generosamente y con gran profesionalidad, han cumplido con los tiempos establecidos en las evaluaciones remitidas. A todos se les ha enviado un certificado de reconocimiento.

Valdría la pena acotar que se siguen recibiendo contribuciones, sin tener que recurrir alllamado que está ocurriendo de muchas revistas internacionales, las cuales inundan los correos de los investigadores, invitándolos a enviar sus trabajos para publicación en sus revistas (muchas que apenas se inician), ofreciendo fechas rápidas para evaluación y publicación. La mayoría de estas revistas exigen un aporte para el análisis y publicación de los trabajos, que resulta bastante oneroso, sobre todo para países considerados del "tercer mundo", por lo que se vislumbra un notable interés económico que habría que vigilar.

Al revisar algunos los indicadores cienciométricos recientes, que establecen ciertos índices o bases de datos para Investigación Clínica, encontramos algunos hallazgos que comentaremos más adelante. En cuanto a los accesos a la revista, la página de Serbiluz es, con abrumadora diferencia, la más utilizada para la consulta de los contenidos de la revista, al igual que para descargar los trabajos, hecho que ocurre al poco tiempo de ser insertados. En 2017 ha llegado a un número de descargas de 103.823. Esto sobre todo se observa a nivel nacional, aunque se notan visitas y descargas de más de 20 países.

Por otro lado, Scielo nos indica que la 
presentación en html, es mucho más visitada que los pdf, con una cantidad de accesos de 145.473 en los ultimos 12 meses. Esta búsqueda, según Scielo, es poco frecuente para los trabajos publicados en inglés, ya que corresponde a solo un $6,8 \%$ del total de los trabajos consultados. Sin embargo, Redalyc recoge que, de los documentos analizados entre octubre 2015 a noviembre 2016, hubo 17.000 descargas, la mayoría proveniente de EEUU $(8499,46,7 \%)$, seguido de China (4062, 22,3\%), México (2519, $13,8 \%$ ), Alemania $(1418,7,8 \%)$ y Venezuela con solo 155 descargas (1\%). A través de nuestra página WEB el acceso es menor, sin embargo nos demuestra un aumento del número de países (más de 60) que ingresan a ella; por supuesto la mayor frecuencia es de Venezuela, pero seguida muy de cerca por México y los EEUU. Este acceso ha mantenido en los últimos años una duración media de la sesión de alrededor de 2 minutos y 2 páginas por sesión. Estos resultados revelan que el acceso al material de la revista es variable, de acuerdo con el buscador.

En relación a los factores de impacto, Investigación Clínica alcanzó en el 2016 un SJR (Scimago Journal Rank) de 0.215, mantuvo el Indice $\mathrm{h}$ de 19 y un valor de citaciones por documento de 0.596, valor que está por encima de muchas revistas latinoamericanas, e indica que aproximadamente un $60 \%$ de los trabajos publicados son citados. Scimago reveló un incremento en la presencia de autores internacionales en los trabajos publicados, de $8,6 \%$ en el año 2015 a $14,3 \%$ en 2016 . Redalyc también reporta un $11,3 \%$ de autoría externa, representada por Mexico con 5,2\%, España con $4,5 \%$ y Colombia y EEUU con $3 \%$. Nuestros archivos revelan un $17 \%$ de autores extranjeros en los trabajos publicados en 2015 y un $23 \%$ en 2016. Para el año 2017, el incremento notable de la autoría externa en los trabajos recibidos, probablemente se reflejará en una mayor proporción de trabajos publicados por autores extranjeros.

El Journal Citation Reports de Thomson Reuters (Science Citation Index Expanded) nos coloca un puntaje de 0.512 en 5 años y reporta 207 citaciones para 2016. En la clasificación del Index Copernicus tenemos 138,01/200 puntos para el el mismo año y el IBI (Factor para Infobase Index) para 2015, fue de 3.6/5. Por otro lado, somos la revista venezolana que tiene más artículos recopilados por Redalyc, con 395.

Finalmente, debemos hacer mención a lo que está sucediendo con nuestra indexación en el PubMed. El MEDLINE está cambiando su plataforma de indexación que ha sido el OCRing, y nos han informado, a comienzos de septiembre, que los trabajos de los números publicados con anterioridad a julio de 2017 irán siendo indexados progresivamente, pero que después de esta fecha se requerirá someter los trabajos a la modalidad XML. Esto representa un reto ya que este sistema es poco conocido en Venezuela y ha sido muy difícil hallar un experto que nos asesore. Afortunadamente, en fecha reciente, hemos suscrito una propuesta de la Corporación Universitaria REMINGTON para colaborar con Investigación Clínica en varios aspectos de su edición, entre ellos el pase de los trabajos a la modalidad XML-JATS. Así que esperamos que el 2018 sea un año más fructífero.

Elena Ryder 


\section{Investigación Clinica resists the influence of the political, economic and social situation in Venezuela.}

Investigación Clínica closes this year 2017 successfully in spite of dealing with a full year of conflicts in Venezuela. Analyzing some scientometrics indicators we found that as far as the accesses to the journal is concerned, there are important variations depending of the finders used. If the page of Serbiluz is used, we reached in 2017, 103,823 downloadings, most of them consisting of national consultations. For Scielo, in the last 12 months we were accessed 145,473 times with a preference of the html form of the papers in Spanish language; while Redalyc informs 17,000 downloadings mainly originating from USA, followed of China and Mexico. In relation to the impact factors we increased the Scimago Journal Rank for 2016 to 0.215 , maintaining an $\mathrm{h}$ index of 19 , and a value of citations by document of 0.596 , that is to say, that near $60 \%$ of the papers were cited. The Journal Citation Report established 0.512 for 5 years and 207 cites for 2016. The evaluation of Index Copernicus for 2016 was 138,01/200 points, and the Infobase Index for 2015 was 3.6/5. As for the international contribution, Scimago revealed the presence of international authors of $14.3 \%$ in 2016 , Redalyc reports a $11.3 \%$ while our archives indicate a $23 \%$ of foreign authors. Finally, we should mention the delay with PubMed citations. This is due to the fact that the new platform of MEDLINE requires that we should transform our contributions to the XML-JATS format, something that has been very difficult to do for us. Fortunately, recently we are establishing an agreement with the UNIREMINGTON Foundation that has made us a proposal to collaborate with the journal in this respect. For this reason, we expect a better 2018 .

Vol. 59(1): 1-4, 2018 